\title{
Carving, Forging, Stealing
}

Writers are natural murderers. Their murderousness is a form of sociopathy, fueled by resentment, scorn, glee and deep affection. - Lynn Freed

I carve out characters. This one is abrupt and says things no one wants to remember saying. That one is generous and funny, and always arrives late. The man - Robert has a dry wit and talks very little except to his son. The boy continually asks questions. These characters are both people in my own life and creations of my fingers on the computer keyboard. When I write down a line of dialogue one of my sisters has said, it is immediately transformed into something said by a character on my page. Even if the words are accurately transcribed from life - and how could they be given I have only a normal faulty memory at my service? - they are changed by being written, by their context, by what I have written above and below them. If I were to read these words to my sister, she might perhaps say, 'that isn't what I said', or 'I didn't mean that', or 'you just made that up, Grace'.

I 'make things up' and then I believe them. I live my life with dual vision. In my interactions with my family and friends I am relating to the flesh and blood person and also to the character I have created on the page. Sometimes the two versions of a person coincide and overlap; sometimes they clash and I look at Ben's father and think, 'what sort of a man are you?' because he is behaving in a way Robert would never behave.

Grace, too, is a character I have created. She is so close to me, I think, that anyone who knew me well would realize that she is a self-portrait. The self-portrait is partial, of course, because I know only some things about myself. But also, it is partial because the act of portrayal, of representation, seems to require some blurring 
and smudging, some cutting and sharpening. Grace is sometimes more naïve than her original, sometimes more shameful; she is weaker. And then sometimes she is wiser than I have ever been and steps back and watches where I would step in and damage. I thought I would be tempted to airbrush Grace, to make her more attractive and better behaved than I feel I really am. But in fact, as I write, Grace quite happily enacts the worst of my behaviour as well as the best. The process of exposure, of revealing myself, seems much less important than the process of telling my story as honestly as I can. My fear that I would self-censor in order to protect myself and others has been unfounded. There is a deeper desire that is so powerful I seem able to sacrifice my own privacy.

A separate question is: how far am I prepared to sacrifice other people's privacy? What betrayals will I perpetrate on others?

When I was twenty and a university student, I fell in love with an English literature lecturer. I knew it was a cliché, even then, and that our affair would end badly for me. He knew that too, of course, and told me so. He was ten years my senior and a published author and I was in awe of him and infatuated. As predicted, things ended unhappily for me and I flew to London with a broken heart while the Poet (as I call him) continued his adulterous married life. For a few years I wrote him sad little letters full of literary devices and pretend pleasures. He occasionally wrote back letters of prevarication, ambivalence and restraint. Just the sight of the looping black letters of my name in his hand drove me to a frenzy of desire and hope, so that I would read the letters with frantic concentration, trying to suck some sustenance from his words. I was always disappointed. I suppose I wanted him to tell me that I was a person of value and loved or at least lovable, but of course he never said such a thing. 
Eventually, I got over my infatuation for the Poet. I grew older; life got busy; I met other men. Now and again, the Poet and I would exchange notes or cards and he always sent me copies of his books. One day, eight years after we parted, I received the Poet's new novel in the post. On the title page, in that same looping hand was written: 'to Grace, at last, with love and gratitude, this house of ghosts and memories'. To say that I was a character in that novel would be completely untrue. But still, I was there. I recognized myself. There was a woman who loved a man without return. That woman was flawed in a particular way and I recognized that flaw. She dreamed a dream that eight years ago was my dream, one I had retold the Poet. In this novel, the woman and the man write letters to each other. The man's letters form part of the novel and these letters I recognized also, because they were only slightly changed versions of those disappointing letters I had received from the Poet in London. I suppose the Poet kept photocopies of all the letters he wrote. The letters are replies to the woman's letters, which the reader never gets to read but which are shaped in our minds by the nature of her ex-lover's replies.

It's a common enough story. Writers use real life as their material. They write down interesting conversation and dreams. They go back to their own work - old poems, draft stories, letters to friends - and use the bits they like for their current work. The Poet had never pretended to be a person of outstanding integrity - after all, I got to know him while he cheated on his wife. He had warned me that he would do me no good. Still, in spite of knowing all this, I admit I was shocked and enraged when I read that novel. I wrote him a furious letter, telling him he had betrayed my trust. (Yes, a letter - it seems I never learn from my mistakes.) But mostly, I felt shamed, and this was what stayed with me after the anger and sense of betrayal abated. The shame of the dream. The shame of unrequited love. The shame of his 
representation of me. Most of all, I felt shame that words written in private directly to me by a man I loved were in fact not private, not personal, not a gift to me, but part of a novel.

I did think of revenge. Yes, indeed, I had many fantasies of writing my own story, outing the Poet for adultery and dream-stealing! But revenge, of course, doesn't heal shaming - that is something we have to deal with internally.

This happened a long time ago now and so it is like thinking of something that happened to someone else, not me. Now, I realize that my reactions at the time were coloured by many other things, one of which was my sense that the Poet had stolen my voice. When I met the Poet I was young and hopeful and wanted to be a writer. But I was insecure and somehow ashamed of my desire to write; I felt that I might have no talent. Perhaps I fell for him because he was what I wanted to become. When he rejected me, I managed to translate that into my own rejection of the dream of becoming a writer. This wasn't necessarily a conscious decision. It related in some way to a feeling that my sexual self had been damaged by our relationship. When he replied to my first letter from London saying, 'Your letter is a little selfconscious. You probably will be a writer after all,' I felt terribly humiliated. Deep within me I began to feel that I would never, could never, be a writer.

The Poet, of course, is not to blame for my insecurities as a young woman. In fact, he is not to blame for anything in this story. But I think of it now because I am at risk of doing to others what I once experienced as so painful. In effect to represent others is to steal their story. This can have profound consequences.

Before my son reached the age of four, I had breached his privacy many times. I continue to do this. It is part of living with disability. You are asked to tell your story 
to strangers all the time. What you are asked to tell as a parent is a particular type of story. The scaffolding for the story is provided by the context and the professional you are talking to. When Ben was being diagnosed, I spent hours answering questions put to me by a developmental pediatrician, a psychologist and a speech pathologist. The pediatrician asked about developmental milestones and physical health. The psychologist was interested in play and relationships. The speech pathologist focused on language. All these separate stories came together only in me. I kept trying to return to Ben as a whole person, but then I would get derailed into a detail, like the way he mixed up pronouns or what he did in noisy places. At the end of the process, the pediatrician wrote a five page report on Ben, indicating which of the criteria he met for a diagnosis of autism and why. Reading it was a strange experience. It was true but untrue. It seemed to be less a story about Ben than about a boy who failed to do certain things that his mother and these professionals expected him to do. The woman in the story - that is, me - was also strange. The report was full of phrases like, 'the mother reports that ...' and 'according to the mother'. It was only on reading the report that I realized the extent to which I act as translator and mediator between Ben and the rest of the world. Of course, all parents do this with young children, but I realized then the power that such a role has when your child has a disability.

This was only the start of my form filling and question answering. Now, I am quite used to completing a long and detailed form before I can enroll Ben in any activity or have any new person work with him. I have completed Sensory Profile Questionnaires, school disability funding applications, forms for respite, for special activities, for parent training funds, for adaptive technology, for everything really, even things that we turn out to be ineligible for or unable to use. I have briefed 
psychologists, speech pathologists, occupational therapists, therapy assistants, school teachers, education assistants, sports instructors, swimming teachers, hairdressers, dentists, neighbours and child care providers. Every time I talk about Ben, I am rehearsing his life story, choosing which things I need to say and which I leave out. I am exposing his challenges, anxieties and preoccupations to a stranger, who will work with him for a while, but who usually moves on within less than a year. And each person takes notes. They have a file on Ben at the school, the Disability Services local and head office, the local council, the non-government agency that is supposed to provide services to the school, the respite service we never use, the child care service he is too old to use, the doctor's surgery, the hospital, and at the offices of all our private therapists and all the researchers who have asked us to participate in autism research.

The further I went in my career as a medical subject (oh yes, 'the mother' is a subject too), the more I realized that the process of completing forms and answering questions resulted in a series of stories about Ben (and me) that had the potential to define him. The purpose of giving information to professionals, schools and community groups is to help them work more effectively with your child. That is totally benign. But how benign is it that little pieces of Ben's life are lying around this whole city, out of our control, never retrievable?

The story of the dream-stealing Poet has a postscript. A few years ago a friend told me that she was browsing on the website of a library when she came across the Poet's name. He had sold his manuscripts and letters to this library.

'Did you know he sold his letters to you?' she asked.

'How do you know?' I wondered. 
'Your name's there, Grace, on the website.'

'But I have his letters.'

'But he copied them, didn't he?'

'Oh. So people can read the letters?' This was a silly question, of course, because anyone could read the letters in the novel.

'No, Grace.' My friend gave her wasn't-I-right-after-all sort of smile. 'Some of the folios are closed until after the author's death. His letters to you are in one of those.'

'Until after his death?'

'Yes, that's right. Planning to outlive him, are you?'

One of the things about autism is that researchers love it. This is good because it means there is lots of research going on. (Not that most of it actually helps autistic people live a fuller life.) Researchers, of course, need subjects and in a small city and country that means that parents of autistic children gets lots of inquiries about whether they might participate in some research. At first I was keen because I felt that it was a responsible thing to do and also more information might help Ben in some way. So I filled in sleep diaries and food diaries and did telephone interviews and kept a record of the number of hours of direct intervention Ben received and any results I could observe. And I took Ben for some IQ and behavioural tests - made him sit in small square rooms with me while strangers asked him odd questions.

The event that ended our research participation involved three tests all rolled into one: an EEG, taking blood and a gut permeability test. He was only four years old and I wasn't sure how he would handle this, but I felt it was worth the risk because we would be given the results. Many autistic children suffer from epilepsy and an EEG 
may give some warning or indication of epilepsy in advance. The gut permeability test also provides some indication of food intolerances and so, again, I thought that would be useful information. I suppose it was useful because it showed that Ben's gut seemed normal and that his EEG included some abnormalities but none that especially indicated epilepsy. Still, that information came at some cost to Ben.

It was a Friday. In the morning, Ben had to fast and could drink only water. That wasn't too hard. We had to put anesthetic cream on the inside of his elbows so that he wouldn't feel any pain when they took blood. We used transparent band aids ('like little windows' I said) to keep the cream on. Ben really hated those band aids and kept trying to rip them off and crying when I wouldn't let him. I took him across the road to the park and he sat crying in the swing, saying, 'please take off windows'. An hour later we drove to the children's hospital and entered the neurological suite. This was like any other hospital room except for a few dog-eared children's posters on the walls and some grubby toys in a basket in the waiting room.

'Not exactly welcoming, is it?' murmured Robert.

'Don't like here,' proclaimed Ben.

In order to do the gut permeability test, Ben needed to drink a whole cup full of sugary liquid. When they took blood in an hour's time, they would then test how much of the starch had leaked into the bloodstream. At the same time, Ben had to drink a small dose of cough mixture. For the EEG, he had to be sedated and the least harmful way to sedate a child in terms of research protocol was deemed to be cough mixture. The only problem was, Ben didn't want to drink either of these mixtures and refused. So, I held him down, while Robert and the nurse forced the cough mixture down his throat with a syringe and held his mouth closed until he swallowed. That experience made him even less interested in drinking the sugar liquid. According to 
the nurse, I was to rock Ben to sleep, while making sure he drank the liquid. I did my best. I started with reading him books and singing lullabies. We turned down the lights and I told him to lie down and sleep. It was eleven in the morning; Ben didn't feel sleepy and he certainly couldn't relax in a strange environment, with windows on his elbows and thick fluids being forced down his throat. After some time, the nurse said she would use their second line sedation method - something squirted up his nose. This caused Ben to scream and run to the door, banging on it to be let out. Eventually, he did start tiring, I think partly because he was so scared and upset he had worn himself out. He lay on my lap, arms around my waist, while I recited the times tables to him because I knew that would be the most reassuring thing I could say. The nursed looked at me with slight horror when I changed from 'twinkle twinkle' to 'two times two'. Perhaps she thought I'd lost it. I remember sitting there, muddling up six times seven with six times eight and just carrying on reciting the wrong numbers anyhow. And finally he gave up the struggle and slept.

'He's a fighter,' remarked Robert, patting my back for reassurance.

We laid him on a hard bed and the EEG technician came in and placed electrodes all over his skull before hooking him up to the machine. Then we were asked to leave so that our voices didn't influence the results. We sat with our coffees in the hospital café and did what Robert and I always do at such times, probably what most people do - we told each other what a brave child we had and made black humour jokes at our own expense.

An hour later, the EEG was finished and the final tasks were to take blood and then remove all the electrodes from Ben's head.

'We'll take the blood now,' said the nurse, 'because he's still out to it.' 'He'll wake though, won't he?' asked Robert. 
'Oh no, they never wake.'

Robert and I exchanged a glance. I moved to the head of the bed and Robert stood on one side. As soon as she inserted the needle, Ben woke and started struggling and screaming. Robert and the EEG technician held him down, the nurse took all the blood from one arm - three vials full - while I held Ben's face in my hands, placing my own very close and counted with him. Finally the electrodes came off his head and we could go home.

'He'll be very groggy all day,' warned the nurse, 'he'll probably drop back to sleep in the car or later at home. They always have another nap after sedation.'

Ben wanted to walk to the car park, but his legs kept wobbling, so he allowed Robert to carry him to the car. He didn't sleep in the car - he wanted to eat instead. I put videos of Bananas in Pyjamas on for him in the afternoon and he sat down with his legs splayed like a yoga master and watched them for two hours. He didn't sleep until his normal bedtime.

'Just rock him to sleep. They never wake with the bloods. They always sleep after sedation.' I quoted to Robert in a cruel imitation of the nurse that night.

'Like I say,' said Robert, 'he doesn't give up easily.'

'He doesn't forget, either,' I suggested. And I was right. Regularly, for the next year or so, Ben would refer to that event and ask me why I was so mean, making him wear windows on his elbows and holding him down while the nurse took blood for over 120 counts. He wasn't angry with me or let down so much as mystified and determined to remind me that it wasn't a good experience. He made me promise that I would never do that again to him. It was three years before he would agree to wear another band aid. 
Privacy is about control. Control over our own body, space and possessions and control over information about ourselves. In Secrets, Sissela Bok defines privacy as 'the condition of being protected from unwanted access by others' (10). She says: 'Claims to privacy are claims to control access to what one takes - however grandiosely - to be one's personal domain' (11). Most people see their own bodies, their possessions and their creations as part of their own personal domain. She points out, however, that some parents see their children as part of their own personal domain as well. I think that she would suggest that these parents are being grandiose, because a child is likely to consider him or herself the appropriate person to determine the access others may have to his or her own space and self.

Bok points out that 'unwarranted access' by others can include not only the revelation of personal matters but also simple observation of one's person by others. For example, we may feel our privacy is invaded if we discover that we are under surveillance. In a similar way, writing about someone without revealing any secrets or anything negative may still violate their privacy. Bok argues in favour of 'partial individual control over the degree of secrecy or openness about personal matters' (27). Without such partial control, she says, it would be impossible to 'preserve the indispensable respect for identity' that we should all be able to claim (27). Here Bok is arguing that privacy and identity are closely interwoven.

This is really about power: 'Control over secrecy and openness gives power' (282). When you write autobiographically about yourself and others, you are giving yourself some form of authority in relation to 'the truth' of your tale. Others, including readers, may question that authority, may resist the exercise of your power.

I started writing about my life as a parent in 2003 and never stopped. 
'What are you writing?' my friends and family would ask me occasionally.

'Just about my life,' I would reply, before changing the subject. No one ever said, 'Are you going to publish it?' or 'Am I in it?' I'm not sure if this is indicates the lack of seriousness with which others viewed my writing or just their fine sense of discretion and restraint.

The first time people started to consider that this work would be published was at the University when I enrolled in a Doctor of Creative Arts. Even then, it wasn't something I really focused on until I had to gain approval from the University's Human Research Ethics Committee. I don't think of myself as doing research involving humans. I think of my research as reading books. But because I am writing about my own life and family, including my son, the University considered this research to involve 'human participants'. Should I be seeking informed consent from my family to write about them? Will I cause any harm to them through my research? How can I protect my family from the results of my research? Should Robert act as an advocate for my son and approve my work for publication? These are the sort of questions that I had to ask myself.

They are confronting questions because I think of myself as my son's advocate. I believe that $I$ am the one person standing between him and a cruel, exploitative world. I don't want to see myself in the role of exploiter, even though many people might consider I am exploiting him by writing about him.

In a sense, the Ethics Committee has required me to reframe my thinking around the ethics of writing my life narrative. I have had to shift my frame to compare my own project with other forms of research, such as medical research, ethnography and psychology. There is a strange irony in this because I feel as though I am writing 
partly to question some of the theories resulting from medical and psychological research on autism.

Because the issue troubled me, I talked to several friends about it. In every case, their response was to say that because my motives are pure, I shouldn't have to worry about this.

'You're not writing a show and tell exposé of a famous ex-husband, are you?' said one friend.

'I don't even have an ex-husband,' said I.

'Not yet, anyhow,' she replied (once again proving herself more astute than me).

I can see that the 'pure motive' argument has no credibility in academic or risk management terms. But still, the intention of the writer seems to carry enormous sway in an everyday sense. It's how we judge people normally I suppose.

After a few of these conversations, I realized what was angering and worrying me underneath all of this. And it wasn't being treated as a potentially exploitative parent or being judged as having sinister motives for writing about my family. No, the thing that was bugging me was: this was my story and I wanted to write it my way, without censorship. I recognize that this is a black and white position and that all scholarship and creative writing involves compromise, but that wasn't how I felt. I also recognized that I would have to compromise in order to protect my son and that protecting my son is very important to me, but still, I didn't want to compromise. I'm not sure how I feel about this. On the one hand, I'm a little horrified at my own desire to write my life my way regardless. On the other hand, I'm rather amazed and impressed at myself that after forty years of not saying what I want, I'm finally determined to. I see that I have a kind of ruthlessness that is troubling and reassuring at the same time. 
It's probably good that the University Ethics Committee didn't know about the ruthlessness!

Questions of privacy and the ownership of one's own story are complicated, of course, by contemporary views of the self. It makes sense to talk about protecting a boy's privacy from his mother's desire to violate it in a life narrative if we have a model of identity that involves a discrete, autonomous self. But contemporary models of identity are much more fluid and relational, reflecting the idea of the self-inprocess rather than a fixed, unitary self. The individual, fixed humanist self may very well be the model of identity many of us use in our daily life and in institutions (such as the law for example), but it isn't going to be very useful for discussions around contemporary activities such as life writing, which enact and represent relational and fluid selves in process. Paul John Eakin says: 'The currency of hybrid forms in contemporary life writing points up the limitations of generic classifications focused on individual selves and lives as discrete entities. An ethics of life writing founded on the inviolate personality becomes similarly problematic' (181). Later in How our lives become stories, he suggests that: 'If our identities and lives are more entangled with those of others than we tend to acknowledge in the culture of individualism, then existing models of privacy, personhood, and ethics may have to be revised' (186). Eakin analyses Roth's memoir of his father, Patrimony, and suggests that Roth both transgresses his father's privacy and has profound respect for the integrity of his father's person and that he is able to do so partly because of the relational nature of his memoir.

Writing about a child seems the closest of all relational memoirs to me. I think this is because as a mother my own body was once my son's first home. In everyday 
life we may think of our body as our most tangible and permanent boundary, but in fact, the body, too, is permeable and fragmented. Sidonie Smith suggests that 'The body is our most material site of potential homelessness' (267). She argues that a history of the body is inscribed in all women's autobiography in one way or another. For a mother, writing about your child is, in one sense, writing the history of your body.

I think it must be true that I don't learn from my mistakes because my lover M is also a poet. Even though we live in different cities, we don't write each other letters. Sometimes, though, we will send a brief email - the sort you might send to any friend. He sends me poems too and sometimes the inspiration for these poems is something I have said or done. But I have no fears from this poet. After forty it's much harder to feel betrayed or shamed by people! Last time I saw him, I asked him if he minded my putting him in my book under a different name. He smiled in that way that crinkles his eyes and stretches his lips thin and said, 'of course not'.

Other people won't feel the same as M. They will be angry and hurt that I have written about them. Changing names won't change their feelings. They will feel this even if I make it clear that what I have written is not 'the truth' but only 'my truth'. Even if I called my work fiction, I may still hurt others. Lynn Freed says that writers, when faced with a choice between truth and decency, will always choose truth. She describes this as a form of 'pathological ruthlessness': 'It involves not only the obvious indecencies, the revelation of bathroom habits and petty adulteries, but, more than this, the revelation, through the story, through the characters in the story, of the human condition itself - its sadness, its absurdity, its loneliness, its familiarity. Is 
there a safe and decent way to accomplish this? I don't think so. If it is done right, someone will be hurt.' (38).

I have no idea how to navigate my way through this issue. I thought at first that perhaps if it is my own bathroom habits and petty adulteries I reveal then this would be a safe and decent way to write autobiography. But it isn't that simple. My life is so linked to others that they are implicated too.

Then I thought that if I stuck to verifiable facts, I would at least be honest if not decent. But the act of writing about verifiable facts changes them. Leigh Gilmore says, 'in telling the truth, autobiographers usually narrate, and thereby shift the emphasis to telling the truth' (68). As soon as we start narrating, the cultural possibilities of narration itself begin to scaffold our story. Writing your life gives you immense power in one way and almost none in another.

The story of the dream-stealing Poet has another postscript. When I was writing this essay, I needed to look in the Poet's novel to discover what it was he had written inside. In my mind I thought it was something a bit pretentious and impersonal. When I read his words I was surprised: they seemed personal, generous and not at all pretentious. I hadn't remembered that he had sent me 'love and gratitude'. The love part I understand. Even though at twenty one I was quite sure he didn't love me, I have since realized the many and varied forms that love can take. But gratitude is more complex. What had he to thank me for, I wonder.

I then flicked through the novel, something I hadn't done for many years. I quickly found the page with 'my' dream. Another surprise: it wasn't an exact reproduction of my dream after all. It was close; two of the images were from my dream, but the sequence wasn't exactly the same. I know this because I kept a dream 
diary in my twenties. I lost the diary ages ago, but found it in a box of papers when I last moved house. The diary had stayed in the box (in company with many earwigs, spiders and other creatures) from then until now.

Years too late, I feel great compassion for the Poet, and indeed for my then self.

Like me, Ben is very interested in stories. Like me, he gets muddled about versions of truth, self and reality.

'Mum, what do real unicorns look like?' he will ask. Or, 'Is this a fiction or nonfiction story?' I often find it quite difficult to answer because his stories are both true and make-believe at once. To create his stories he mixes the plot from books we have read together with events from his life. For example, he will take the basic structure of Beatrix Potter's The Story of a Fierce Bad Rabbit, change the rabbits to a frog and a toad and then elaborate along the lines of bad and good things he does at home and what happens to the good frog and bad toad. The protagonist of most of Ben's stories is Frog, his alter ego. So it seems that Ben, too, is writing his autobiography. But - as he often says when I try to move him from one subject to another - 'that's another story'.

Names in this essay have been changed to protect privacy.

\section{Works Cited}

Bok, Sissela (1983). Secrets: on the ethics of concealment and revelation. New York, Vintage.

Eakin, Paul John (1999). How our lives become stories: making selves. Ithaca, New York, Cornell University Press. 
Freed, Lynn (2005). Reading, Writing and Leaving Home: Life on the Page. Orlando, Florida, Harcourt Books.

Gilmore, Leigh (1994). 'Policing Truth: Confession, Gender and Autobiographical Authority' in Ashley, Kathleen, Gilmore, Leigh and Peters, Gerald (eds) (1994). Autobiography and Postmodernism. Boston, University of Massachusetts.

Smith, Sidonie (1994). 'Identity’s Body’ in Ashley, Kathleen, Gilmore, Leigh and Peters, Gerald (eds) (1994). Autobiography and Postmodernism. Boston, University of Massachusetts. 